\title{
PIERCING THE VEIL OF CHINA'S LEGAL MARKET: WILL GATS MAKE CHINA MORE ACCESSIBLE FOR U.S. LAW FIRMS?
}

\author{
Richard Qiang Guo*
}

\section{INTRODUCTION}

Beijing is in the triumphant rapture. After fifteen years of protracted negotiations, China legally became a member of the World Trade Organization (WTO) on December 11, 2001.' Beijing is also victorious because the International Olympic Committee (IOC) has chosen it to host the 2008 Summer Olympic Games, a dream-come-true achieved only after painstaking effort and perseverance. The Chinese, who make up nearly onefourth of the world's population, are ready to put their wisdom, strength, and character to the ultimate test in the coming years. ${ }^{2}$

American lawyers are by no means strangers to China. Their wisdom was relied upon in the founding of the National Council for U.S.- China Trade, Inc. (the predecessor of the U.S.- China Business Council), the first non-governmental organization to promote trade relations with China. ${ }^{3}$ It opened its first office in China in October 1973, at the Dong Fang Hotel in Guangzhou, to provide aid to Americans attending the so-called "Canton Fair." All this happened even before China's own system of lawyers reemerged in $1980 .{ }^{5}$ Given the current jubilation in China over the accession to

* J.D., New York University School of Law (2001); LL.B, LL.M., China University of Political Science and Law (1995). I would like to thank Professor Jerome A. Cohen for his encouragement and enlightening comments. I also benefited from the discussions with Hongming Xiao, a former PRC Ministry of Justice official who attended negotiations in Geneva on legal services, and my friend Warren Hua, J.D., NYU School of Law (2002).

1. See generally Information Paper on the Impact and Challenges for the Hong Kong Legal Profession upon China's Accession to the WTO, HONG KONG DEPARTMENT OF JUSTICE, LEGALPOLICYDIVISION 1 (Dec. 2001), available at http://www.info.gov.hk/justice/new/depart/ doc/ipaper281201e.pdf (last visited Sept. 15, 2002) [hereinafter Information Paper]. On Sept. 17, 2001, the Working Party on China's accession to the WTO successfully concluded negotiations on China's terms of membership in the WTO, paving the way for the text of the agreement to be adopted formally at the Fourth WTO Ministerial Conference in Doha, Qatar, Nov. 9-13, 2001. See id.

2. See Tamara Loomis, Will China Be Boon for Lawyers?, 224 N.Y.L.J. 5 (2000). The US-China Business Council is a Washington, D.C.-based trade association composed of 250 companies and law firms. See id.

3. See generally Eugene Theroux, The Formation of the US-China Business Council: A Look at the Score, CHINA BUS. REv., July 1, 1993.

4. See id.

5. See generally Qizhi Luo, Autonomy, Qualification and Professionalism of the PRC Bar, 12 CoLUM. J. ASIAN L. 1 (1998). The Cultural Revolution totally dismantled the fragile primitive lawyer system of the 1950s. See id at 8-9. See also Randy Peerenboom, The Legal Profession, in DOING Business IN CHINA 2-6 (2000). 
the WTO and selection by the IOC, considering the seemingly enormous investment opportunities for their clients, it seems odd that the mood of American law firms with China in mind is only "cautiously optimistic," according to John Ford, vice president of the U.S.- China Business Council. ${ }^{6}$

The past three decades have seen the influx of foreign investment in China, in which U.S. lawyers have played crucial roles. While their clients are partying with Chinese landlords, the lawyers are still lingering at China's doorway, trying hard to receive an official invitation to be invited in. "It was a bit like studying the moon: [y] ou could see it, but you couldn't get there," recalled Professor Jerome Cohen, who engineered the Coudert Brothers' Beijing office, the first foreign law firm to have a foothold in mainland China since the Communist takeover.?

China has earned a reputation of "being inhospitable to foreign business, ${ }^{18}$ but has been much more suspicious of foreign lawyers. Tight regulations for foreign law firms operating in China has sparked a firestorm of debate. To some extent regulation is justifiable because in China, the practice of law is to a large extent still a public function. ${ }^{9}$ For one thing, western lawyers can by no means possess the national loyalty and shared cultural values, which are still prerequisites, though not literally, of the socialist regime. ${ }^{10}$

Nevertheless, how much leverage does a sovereign state like China have in regulating foreign access into its legal market? Is there a minimum international standard that universally applies to regulation of domestic legal markets? How should sovereign nations like China cope with the right to regulate and the duty to grant access? This article will explore the international rules governing trade in legal services, specifically the General Agreement on Trade in Services (GATS), briefly discuss the Chinese

6. See Loomis, supra note 2.

7. Douglas McCollam, Let A Thousand Branch Offices Bloom, 22 AM. LAW. 92 (2000), available at http://www.law.com/cgi-bin/gx.cgi/AppLogic+FTContentServer?pagename=law/ View\&c=Article\&cid=ZZZU98Q8QEC\&live=true $\& c s t=1 \& p c=0 \& p a=0$ (last visited Aug. 30, 2002).

8. Kevin Livingston, The China Syndrome, THE RECORDER, Nov. 15, 1999, available at http://www.law.com/cgi-bin/gx.cgi/AppLogic+FTContentServer?pagename=law/View\&c= Article\&cid=A9934-1999 Nov 18\&live=true\&cst $=1 \& p c=0 \& p a=0$ (last visited Aug. 30, 2002).

9. See WTO SECRETARIAT, GUIDE TOTHE GATS: ANOVERVIEW OF ISSUES FOR FURTHER LIBERALIZATION OFTRADE IN SERVICES 407 (2001). According to WTO Secretariat, countries that maintain a nationality requirement in relation to the provision of legal services appear to do so to protect a "public function" performed by host-country practitioners involved in the practice of host-country law, particularly in relation to representation associated with a right of audience in the courts of host jurisdictions. See id.

10. See, e.g., Zongze Gao, President, All-China Bar Association, speech at the WTO on the China Legal Profession Conference (transcript, available at http://www.chineselawyer .com.cn/article/show.php?cId=736) (last visited Aug. 30, 2002). Zongze Gao stated that one of the achievements in Chinese legal market is the emergence of an echelon of lawyers of higher political consciousness and professional caliber, whom the Community Party and the people trust. See id. 
regulatory regime regarding foreign law firms, and offer an historical review of the inroads that American law firms have made into the Chinese legal market. The article will conclude by gauging the potential impact that China's accession to the WTO is likely to have on China-oriented American law firms.

\section{GATS AND TRADE IN LEGAL SERVICES}

As the "first ever set of multilateral, legally-enforceable rules covering international trade in services," publicity. ${ }^{12}$ Trade in services was included in the multilateral General Agreement on Tariffs and Trade (GATT) negotiations only upon the reluctant agreement of many developing countries. ${ }^{13}$ Because a large share of trade in services takes place inside national economies, ${ }^{14}$ the nature of the services makes any international body of law like GATS more intrusive than other trade legislation. ${ }^{15}$ For the same reason, critics have claimed that liberalization under GATS means deregulation of services, ${ }^{16}$ and as a result governments pay a high price from losing the right to regulate, ${ }^{17}$ threatening democracy. ${ }^{18}$ On the other hand, proponents of international cooperation in liberalizing trade in services criticize that too much flexibility in scheduling services makes GATS systematically an ineffective vehicle by which to liberalize trade in services. ${ }^{19}$ Still no substantial improvement of market access has been achieved because most commitments merely preserve existing regulatory measures. ${ }^{20}$

11. Trading Into the Future, The Introduction to the WTO (2001), available at http:/I www.wto.org/english/thewto_e/whatis_e/tif_e/agrm5_e.htm (last visited Sept. 28, 2002) [hereinafter Trading into the Future].

12. See generally GATS - Fact and Fiction, available at http://www.wto.org/english/ tratop_e/serv_e/gatsfacts 1004_e.pdf(last visited Aug. 30, 2002) [hereinafter Fact and Fiction].

13. See Mara M. Burr, Will the General Agreement on Trade in Services Result in International Standards for Lawyers and Access to the World Market?, 20 HAMLINE L. REV. 667,670 (1997).

14. See An Introduction to the GATS, available at http://www.wto.org/english/tratop_e/ serv_e/gsintr_e.doc (last visited Aug. 30, 2002).

15. See Jessica Woodroffe, GATS: A Disservice to the Poor, WORLD DEVELOPMENT MOVEMENT, 32 (2002), at http://www.wdm org.uk/cambriefs/gatsdiss.pdf(last visited Aug. 30, 2002).

16. See Fact and Fiction, supra note 12, at 11.

17. See id. at 10.

18. See, e.g., Scott Sinclair, GATS: How the World Trade Organization's New "Services" Negotiations Threaten Democracy, CAN. CENTRE FOR POL'Y ALTERNATIVES (Sept. 2001), at http://www.policyalternatives.ca/publications/gatssummary.html (last visited Aug. 30, 2002).

19. See Michael J. Chapman \& Paul J. Tauber, Liberalizing International Trade In Legal Services: A Proposal For An Annex On Legal Services Under the General Agreement On Trade In Services, 16 MiCH. J. INT . 941, 967-72 (1995).

20. JEFFREY S. THOMAS \& MiCHAEL A. MEYER, THE NEW RULES OF GLOBAL TRADE: A GUIDE TO THE WORLD TRADE ORGANIZATION 248-50 (1997). 


\section{A. GATS: Liberalization or Deregulation?}

Negotiated in the Uruguay Round, ${ }^{21}$ GATS covers all internationallytraded services with two exceptions. ${ }^{22}$ Like the agreements on goods, ${ }^{23}$ GATS operates on three levels: (1) the main text containing general principles and obligations; (2) annexes dealing with rules for specific sectors; ${ }^{24}$ and (3) individual countries' specific commitments to provide access to their markets. ${ }^{25}$ Unlike the agreement on goods, GATS has a fourth element showing which countries are temporarily not applying the "most-favorednation" (MFN) principle of non-discrimination. ${ }^{26}$

MFN treatment under GATS directly parallels the centrally important Article I of the GATT. ${ }^{27}$ Article II of GATS provides that "with respect to any measure covered by this Agreement, each Member shall accord immediately and unconditionally to services and service suppliers of any other Member treatment no less favorable than that it accords to like services and service suppliers of any other country."28 Article II further establishes a general obligation which is in principle applicable across the board by all Members to all service sectors, regardless of whether the member has undertaken specific commitments in a sector. ${ }^{29}$ This provision requires a country allowing foreign competition in a service sector, to give equal opportunities in the sector to service providers from all other WTO members.

However, under GATS, any member can also apply for a one-time temporary exemption from MFN by listing a service sector in the Annex on Article II Exemption. In order to protect the general MFN principle, such

21. See Trading into the Future, supra note 11 . The Uruguay Round negotiation was launched in Punta del Este, Uruguay, in September 1986, and the Final Act embodying the results of the Uruguay Round of multilateral trade negotiations was signed by ministers in Marrakesh on April 15, 1994. See id. The Final Act is 550 pages long and contains the legal texts, which spell out the results of the negotiations including those on legal services. See id.

22. See Fact and Fiction, supra note 12, at 1 . The two exceptions are "services provided to the public in the exercise of governmental authority and, in the air transport sector, traffic rights and all services directly related to the exercise of traffic rights." Id.

23. See Trading into the Future, supra note 11, at 14. The General Agreement on Tariffs and Trade (GATT) deals with trade in goods. The text of GATT 1947 has been amended and incorporated into the new WTO agreements and known as "GATT 1994." See id.

24. See General Agreement on Trade in Services, in Unuguay Round Final Act, Dec. 15, 1993, Annex 1B, GATT Doc. No. MTN/FA, 33 I.L.M. 1130 (1994). See art. XXIX (Jan. 2000), available at http://www.wto.org/English/docs_e/legal_e/legal_e.htm=services [hereinafter GATS]. There are eight annexes on Article II exemptions including: movement of natural persons supplying services, air transport services, financial services (two annexes), maritime transport services, telecommunications and negotiations on basic telecommunications respectively. See id.

25. See Fact and Fiction, supra note 12, at 1.

26. Trading Into the Future, supra note 11, at 21.

27. See An Introduction to the GATS, supra note 14, at 4.

28. GATS, supra note 24, art. II, para. 1 (emphasis added).

29. See Trading Into the Future, supra note 11, at 21. 
exemptions are only made once and must be taken at the time the negotiations were concluded. ${ }^{30}$ Exemptions last for not more than ten years and are subject to review after not more than five years (in 2000). ${ }^{31}$ Subsequently, any future requests for exemptions from Article II are only granted under the waiver procedures of the Marrakesh Agreement. ${ }^{32}$ In other words, an MFN exemption would give a Member who had made no commitments in a sector considerable freedom to discriminate. ${ }^{33}$ Therefore, in such cases, a Member may accord treatment more favorable than the minimum standard to some Members, as long as all Members receive at least that minimum standard of market access and national treatment appearing in its schedule. ${ }^{34}$

This automatic extension of any bilaterally or multilaterally negotiated privileges amongst WTO members creates classic free-rider concern. ${ }^{35}$ A member that has a restrictive policy and does not make a commitment in a particular service sector can maintain its status quo and free ride on other members who, through time-consuming negotiations and bargains, grant each other improved access to this service sector in their jurisdictions. ${ }^{36}$

As a matter of fact, even during the bargaining, Members may try to free ride on each other, as was alleged in the context of the financial services and telecommunications negotiations. ${ }^{37}$

Each of the beneficiaries of a concession from a trading partner may be tempted to understate their willingness to pay for it, hoping that offers of reciprocal concessions from other

30. See id. at 24.

31. See id.

32. See General Agreement on Tariffs and Trade 1994, Apr. 15, 1994, reprinted in 33 I.L.M. 1154 (1994) [hereinafter Marrakesh Agreement], also available at http:/www.wto.org/ english/docs_e/legal_e/04-wto.pdf (last visited Aug. 30, 2002).

33. See Aaditya Mattoo, Most Favored Nation Status and GATS, speech presented at the World Trade Forum Conference on Most Favored Nation Status (Aug. 28-29, 1998) at 7-8 (transcript available at $\mathrm{http}$ //wwwl .worldbank.org/wbiep/trade/papers_2000/BPmfn.pdf) (last visited Aug. 30, 2002).

34. See Guide to Reading the GATS Schedules of Specific Commitments and the List of Article II (MFN) Exemptions, available at http://www.wto.org/english/tratop_e/serv_el guidel_e.htm (last visited Aug. 30, 2002). "At the time of the signature of the Final Act of the Uruguay Round on April 15, 1994, 95 schedules of specific commitments in services and 61 lists of derogation from the MFN principle were submitted and agreed upon." Id.

35. JOHN H. JACKSON, THE WORLD TRADING SYSTEM: LAW \& POLICY OFINTERNATIONAL ECONOMIC RELATIONS 136-38 (1994).

36. See, e.g., Weitian Zhao, ZuI Hui Guo Yu Duo Bian Mao Yi Ti ZHI 47 (1996). There is yet another possible free-riding problem when MFN "spills" out of WTO. See id. For instance, A and B are both GATS members. A owes MFN to C, who is not a member of GATS, under a bilateral treaty. See id. C could be able to enjoy all benefits A gives to B, which are the results of a multilateralized negotiation during which B presumably had traded away certain commitments, without having to fulfill any GATS obligations- since it is not a party of GATS. See id.

37. See Mattoo, supra note 33, at 31. 
Members will be sufficient to induce the concession.... This was reflected in the unwillingness in some of the services negotiations of some Members to make binding commitments unless a certain 'critical mass' of Members was willing to make significant liberalization commitments. ${ }^{38}$

Thus, free-rider concern seems to be the major driving force of Members taking actions to claim MFN exemption. There are at least two other reasons. First, when GATS came into force a number of countries already had preferential agreements in services that they had signed with trading partners, either bilaterally or in small groups. ${ }^{39}$ WTO members felt it was necessary to maintain these preferences temporarily. They gave themselves the right to continue giving more favorable treatment to particular countries in particular service activities by listing "MFN exemptions" alongside their first sets of commitments. ${ }^{40}$ Second, "[c]ertain sectoral sensitivities that emerged in the Uruguay Round raised the specter of wholesale sectoral exclusions from GATS as a means of avoiding the MFN rule. In order to prevent this, it was agreed to permit limited exemptions to MFN under GATS."41

It became clear during the Uruguay Round that "unqualified liberalization in some service sectors could not be achieved, and that liberalization subject to some temporary MFN exceptions would be preferable to no liberalization at all."42 According to the Secretariat, GATS rules including the one-time MFN exemption provide remarkable flexibility that allows governments, to a great extent, to determine the level of obligations they will assume. ${ }^{43}$ "It was this flexibility in the scheduling of commitments which put an end to the north-south controversy over services which marked the early years of the Uruguay Round." 44

There are at least three other main elements of remarkable flexibility in GATS: (1) complete freedom to choose which services to commit, i.e., to guarantee access to foreign suppliers; (2) for those services that are committed, the ability to set limitations specifying the level of market access and the degree of national treatment they are prepared to guarantee; and (3) the ablity to limit commitments, or withdraw and negotiate commitments, to one or more of the four recognized "modes of supply" through which services

38. Id.

39. See Trading Into the Future, supra note 11 , at 24.

40. See id.

41. Mattoo, supra note 33, at 6.

42. An Introduction to the GATS, supra note 14 , at 4.

43. See Fact and Fiction, supra note 12, at 7.

44. Id. 
are traded..$^{45}$ In this sense, GATS is a product of compromise. ${ }^{46}$ However, as the first set of legally-enforceable rules covering international trade in services, GATS rules do have teeth. One important bite comes from the socalled "specific commitment" approach.

Specific commitments are individual countries' commitments to open markets in specific sectors. ${ }^{47}$ The commitments appear in "schedules" that list the sectors being opened, the extent of market access being given in those sectors (e.g. whether there are any restrictions on foreign ownership), and any limitations on national treatment (whether some rights granted to local companies will not be granted to foreign companies).$^{48}$ National treatment is thus treated differently for services than for goods (GATT) and intellectual property (TRIPS) ${ }^{49}$ where national treatment is a general principle. In GATS, national treatment is a "specific commitment"-one of the negotiated rights/obligations-and only applies where a country has made a specific commitment, and exemptions are allowed. ${ }^{50}$

These commitments on national treatment and market access are "bound" 1 and, "like bound tariffs, they can only be modified or withdrawn after negotiations with affected countries, which would probably lead to compensation. Because "unbinding" is difficult, the commitments are virtually guaranteed conditions for foreign exporters and importers of services and investors in the sector to do business." ${ }^{52}$ In light of the keen concerns over deregulation and threat to democracy, it is unfair to expect GATS to achieve the same extent of liberalization as the GATT has done over half a century. ${ }^{53}$ "[T] $]$ he Uruguay Round services package is only a beginning," and, as such, the primary gain in the first round of commitments consisted of commitments not to increase protectionism (standstill commitments), rather than major advances in trade liberalization..$^{55}$ In consideration of this, in

45. See id. However, the withdrawals are actually very difficult to achieve. See infra, Part II.B (regarding "unbinding" commitments).

46. See generally An Introduction to the GATS, supra note 14, at 7 . This can be attributed, at least partially, to the fact that "services negotiations in the Uruguay Round were completed under extreme pressure of time." Id.

47. See Trading Into the Future, supra note 11, at 22.

48. See id.

49. See generally Frequently asked Questions about TRIPS in the WTO, available at http://www.wto.org/english/tratop_e/trips_e/tripfq.e.htm (last visited Sept. 24, 2002). The Agreement on Trade-Related Aspects of Intellectual Property Rights (TRIPS) is one of the three "pillars" of the WTO, the other two being trade in goods and trade in services. See id.

50. See Trading Into the Future, supra note 11, at 23.

51. Id. at 22.

52. Id.

53. See ThOMAS \& MEYeR, supra note 20 , at 250.

54. An Introduction to the GATS, supra note 14 , at 1.

55. See International Trade Forum, General Agreement on Trade in Services Opportunities for Developing Countries, available at http://www.intracen.org/worldtradenet/ docs/information/forum1_2000.htm (last visited Aug. 30, 2002). 
contrast to GATT 1947 , GATS incorporates not only specific commitments to prevent further trade restrictions but also the requirement to engage in ongoing rounds of negotiations for progressive liberalization. ${ }^{56}$

\section{B. Trade in Legal Services: Special Dilemma Created by Unconditional MFN}

As discussed above, only those nations who have chosen legal services to commit are bound to accept the GATS rules as applied to the legal services sector. ${ }^{57}$ However, "the legal profession has unique characteristics arising from its role as intermediary between the citizen and the law and between the citizen and the state. At their core, the activities of the legal profession involve the execution of public duties, not the trade of services." 58

Therefore, legal service negotiators face a special dilemma created by an inherent tension between the GATS approach, unconditional MFN, and intense national concerns about reciprocity in negotiations involving legal services, thanks to the mandatory extension of any bilaterally negotiated benefits under MFN principle. ${ }^{59}$ As the Secretariat puts it, "[t]he main obstacle to trade in legal services is represented by the predominantly national character of the law and by the national character of legal education."60

The legal profession was originally organized around courts with lawyers' conventional role being representation before a court and each bar associated to a specific local court. ${ }^{61}$ Thus, local court/local bar/local lawyer had been a paradigm before the emergence of a new class of lawyers known as transactional lawyers who advise on matters involving transactions, relationships and disputes not necessarily entailing court proceedings. ${ }^{62}$ The legal profession has been further internationalized, driven by corporate clients who do business across borders and choose to rely on the services of professionals who are already familiar with their business and can guarantee high quality services. ${ }^{63}$

56. See Fact and Fiction, supra note 12, at 2. In January 2000, WTO Member Governments started a new round of negotiations. See id.

57. See supra Part II. A regarding "specific commitments."

58. Canadian Bar Association, Submission on the General Agreement on Trade in Services and the Legal Profession: The Accountancy Disciplines as a Model for the Legal Profession 1 (2000), available at http://www.cba.org/epiigram/november 2000/pdf/00\% 2D30\%2Deng.pdf (last visited Aug. 30, 2002).

59. See Chapman \& Tauber, supra note 19, at 971.

60. WTO Council for Trade in Services, Background Note by the Secretariat, S/C/W/43(1998), 15 available at http://docsonline.wto.org/gen_search.asp (last visited Sept. 3, 2002) [hereinafter Background Note].

61. See id. $\mathbf{1 0 .}$

62. See id.

63. See id. 13. 
Legal services, for the purpose of GATS, include any advisory (counseling) or (court) representation service which is supplied on a commercial basis or in competition with one or more service suppliers. ${ }^{64}$ "Completely excluded from the scope of the GATS are services supplied in the exercise of governmental authority, defined as services supplied neither on a commercial basis, nor in competition with one or more service suppliers." 65 In the WTO's Services Sectorial Classification List, "legal services" is listed as a sub-sector of "business services" and "professional services." This entry corresponds to the UN CPC No. 861 in the United Nations Provisional Central Product Classification. ${ }^{67}$ This classification, however, does not reflect the reality of trade in legal services.$^{68}$ In scheduling GATS commitments, Members have preferred "to adopt the following distinctions to express different degrees of market openness in legal services: (a) host country law (advisory/representation); (b) home country law and/or third country law (advisory/representation); (c) international law (advisory/representations); (d) legal documentation and certification services; (e) other advisory and information services."69

Like all services, there are four modes of supply of legal services: (1) cross-border supply when a legal service crosses a national frontier; (2) consumption abroad- when Member's residents purchase legal services in the territory of another Member; (3) commercial presence, i.e., involving foreign direct investment; and (4) movement of individuals-when independent service

64. See World Trade Organization: Council for Trade in Services Special SESSION, Communication From the United States (Legal Services), S/CSS/W28 (Dec. 18, 2000). The U.S. suggests that the classification should be understood to include the provision of legal advice or legal representation in such capacities as "counseling in business transactions, participation in the governance of business organizations, mediation, arbitration and similar dispute resolution services, public advocacy, and lobbying." Id.

65. Mattoo, supra note 33, at 4 n.2. Services supplied in the exercise of governmental authority would include all the activities relating to the administration of justice (judges, court clerks, public prosecutors, state advocates, etc.) See Background Note, supra note 66, I 15. In China, notarial activities were regarded as "services supplied in the exercise of governmental authority." Id. However, Chinese notaries often supply their services "on a commercial basis," and therefore shall be subject to the provisions of the GATS. See id. $q 3$.

66. See WTO SECRETARIAT, Services Sectoral Classification List, MTN.GNS/W/120. (May 24, 1991).

67. See Background Note, supra note $60,916$.

68. See id. 917.

69. Id. Australia has proposed to change the WTO services classification, since the structure of the WTO schedules is better suited to accommodating definitions focused on the area of law and type of service, rather than on the definition of the service provider. See WORLD Trade Organization: Council for Trade in SeRvices SPECIal. Session, CommitTeE on SPECIFIC COMMTMENTS, Communication From Australia, Negotiating Proposal: Legal Services Classification Supplement, S/CSS/W/67/Supp.2 (Mar. 11, 2002), at 3-4. The proposed subcategories would provide the members with a clear mechanism through which to limit the practice of "host-country law (representation services)" to local practitioners, but make substantial commitments through other subcategories, thus protecting the "public function" as well as providing meaningful market access to foreign legal practitioners. See id. 
providers or employees of a multinational firm move to and stay in, temporarily, another country to provide legal service. ${ }^{70}$

Legal services were first included in the GATS negotiations at the insistence of the United States in the Uruguay Round Negotiation. ${ }^{11}$

In the Uruguay Round, 45 members (counting the then 12 Member States of the EU as one) made commitments in legal services. Two acceding members also included legal services in their schedule. Of these 47 members, 22 made commitments in advisory host country law (19 in representation), 41 in advisory international law (20 in representation), 40 in advisory home country law (20 in representation) 41 in advisory third country law and 6 in other legal services (including legal documentation and certification services and other advisory and information services). ${ }^{72}$

U.S. negotiators initially envisioned a special annex on legal services, similar to the Annex on Financial Services, to specifically address the regulatory barriers facing lawyers. Under the terms of the GATS, obligations of such an annex would be binding on all GATS members and would have required all GATS members to afford foreign lawyers some uniform minimum level of access to their legal markets. ${ }^{73}$

Because an Annex is an integral part of the Agreement, binding on all members for the covered sector, the creation of an Annex on legal services, the argument went on, could have eased the inherent tension between the GATS approach and the national concerns. ${ }^{74}$

The final version of the GATS expressly rejected the "Special Annex" approach initially envisioned by U.S. negotiators and, instead, adopted the multilateral negotiation process for the opening of legal markets. ${ }^{75}$ The multilateral negotiation approach permits members to offer improved access to their legal markets in exchange for concessions from other Members-not

70. See Guide to Reading the GATS Schedules of Specific Commitments and the List of Article (MFN) Exemptions, available at http://www.wto.org/english/tratop_e/serv_e/guide 1_e.htm (last visited Nov. 3, 2002).

71. Spencer A. Sherman, Yankee Go Home: What Left for Lawyers After the GATT Debacle, 14 CAL. L. REV. 65 (1994).

72. Background Note, supra note 60, 957. China, siding with Brunei Darussalam, Dominican Republic and Singapore, invoked an MFN exemption for legal services. See Chapman \& Tauber, supra note 19, at 965 n. 146.

73. Id. at 963.

74. See id. at 971.

75. See id. at 963. 
limited within the context of the legal service sector per se, rather, on a more comprehensive service arena, or even across goods, services, investment and intellectual property. ${ }^{76}$

Due to the trade-off feature of such market access negotiations, among the forty-five members, no two Schedules of specific commitments are the same. ${ }^{77}$ A member might want to trade more freedom in its legal market for a similar benefit in another service sector of another member, which it thinks more significant. As a result, the level of liberalization actually achieved in legal services will vary from country to country, "depending on the outcome of various 'horse trades' during the negotiation process."

Still, because offers in the legal service sector are hard to assess due to lack of dependable data and complexity of national regulatory systems, ${ }^{79}$ "legal services suffer from being invariably at the bottom of the [negotiation] agenda." 80

\section{FROM "RECIPROCITY" TO UNCONDITIONAL MFN: CHINA'S MFN SYNDROME}

China entered into GATS negotiation in the Uruguay Round, ${ }^{81}$ submitted its GATS schedules in 1991, 1992, 1994, and 1997, and along with another sixty countries and regions, made the MFN exemption at the time of the signature of the Final Act of the Uruguay Round. ${ }^{82}$

76. See id. at 964.

77. See Background Note, supra note 60, 1 25-27.

78. Chapman \& Tauber, supra note 19, at 964 .

79. See id. at 968-69.

80. Patrick Stewart, Trade War Looms Over Intermational Legal Services, 10 INT'LFIN. L. REv. 19, 20 (1991).

81. See NEwS BACKGROUND, China's Access Into GATT/WTO, available at http://business.sohu.com/991116/file/928noname.html (last visited Aug. 30, 2002). On July 11, 1986, China, an observer at GATT meetings since November 1982, formally applied to resume its GATT membership, which was withdrawn by the Kuo Ming Tang government in 1950 . See id. It received a ermanent observer status on the GATT Council in April 1994, entered into the Uruguay round negotiation on September 15, 1986, and became one of the 123 signatories of the Final Act of the Uruguay Round on April 15, 1994. See id. The nine-year bid, however, failed to bring China into the ortune club when the WTO succeeded the GATT on January 1 , 1995. See id. The WTO accepted China as an observer on July 11, 1995, and the accession negotiation has continued since November 1995 under the framework of the WTO. See id. The multilateral informal negotiation started in Geneva on March 20, 1996, and in October 1996, China undertook a standstill commitment whereby it promised not to introduce any new laws or policy measures inconsistent with WTO rules in the course of negotiation. See Donald C. Clarke, China and the WTO, in DOING BUSINESS IN CHINA, 4 (2000), citing Xiaobing Tang, China Economic System and lts New Role in the World Economy, in CHINA IN THE WORLD TRAding SySTEM: Defining THE PRINCIPLES OF ENGAGEMENT, 58 (1998).

82. See Marrakesh Agreement, supra note 32. 
In response to Members' demand to open up its legal market during the "requests and offers" procedure, ${ }^{83}$ the 1994 schedule $^{84}$ was revised in November 1997 to embody the "legal services" as a sub-sector of "professional services" sector, subject to the MFN exemption based on reciprocity. ${ }^{85}$ Trade in legal services, most significantly, the establishment of business offices of law firms (i.e. the mode 3 of legal service) would be on the basis of reciprocity. ${ }^{86}$

National authorities are very reluctant to tolerate asymmetric access to legal markets, so reciprocity is actually a shared concern. ${ }^{87}$ However, a network of reciprocity provisions in domestic regulations will result in "lowest common denominator liberalization," in which the willingness of the most restrictive country to liberalize its domestic rules decide the pace of actual liberalization. ${ }^{88}$

Chinese negotiators formally gave up the MFN exemption during the accession negotiations. ${ }^{89}$ Only a few days into the WTO fraternity, the central government has already released a new set of regulations in carrying out its WTO commitments. ${ }^{90}$ For instance, on December 22, 2001, the State Council promulgated The Regulations on the Management of Representative Offices set up by Foreign Law Firms in China, (New Regulations) having come into force on January $1,2002 .{ }^{91}$ In conformity with its renouncement of the MFN

83. See Hongming Xiao, The Internationalization of China Legal Services Market, 1 Perspectives 6, at 2-3, at http://www.oycf.org/Perspectives/6_063000/internationalization_ of_china.htm (last visited Sept. 3, 2002).

84. See WORLD TRADE ORGANIZATION, China - Final List Of Article II (MFN) Exemptions (1994), GATS/EL/19GATS/EU19 (Feb. 14, 2002) [hereinafter FINAL LIST].

85. See WORLD TRADE ORGANIZATION, 1997 Schedule, WT/ACC/CHN/12 (Nov. 20, 1997) [hereinafter 1997 Schedule] (complete copy unavailable at time of publication).

86. See id. It is important to distinguish between reciprocity as an aspect of the bargaining process and reciprocity as an aspect of the trade regime. In the former case, concessions are negotiated on a reciprocal basis and the results are multilateralized, so discrimination is not practiced in actual trade. In the latter case, reciprocity is the basis for the implementation of trade policy, so discrimination is a feature of actual trade policy. For purpose of this article, reciprocity means the latter. See Mattoo, supra note 33, at 30.

87. See Chapman \& Tauber, supra note 19, at 962 . Although few countries made MFN exemption-whether it is based on reciprocity or not-in GATS negotiations, reciprocity requirements are very common in domestic rules. See id. See also Background Note, supra note 60 .

88. See Chapman \& Tauber, supra note 19, at 963.

89. See FINAL LIST, supra note 84.

90. See China In Compliance with WTO Accession Commitments, available at http://www.moftec.gov.cn/moftec_cn/wto/wtol l.html (last visited Nov, 3, 2002).

91. See Hong Kong SpeCIAL ADMIN. Region Gov'T DePT. OF Justice, Mainland Regulations Relating to Legal Services at http://www.info.gov.hk/justice/new/depart/ doc/setup_law_firm_e2.pdf (last modified Aug. 20, 2002). To implement the Regulations, the Ministry of Justice issued the Stipulations Concerning the Enforcement of the "Regulations on the Management of Representative Offices set up by Foreign Law Firms in China, effective on September 1, 2002, available at http://www.info.gov.hk/justice/new/depart/doc/setup_law_ firm_e4.pdf [hereinafter Stipulations]. For a commentary on the implementing measures, see 
exemption, New Regulations write off the reciprocity provision of the Provisional Regulations. ${ }^{92}$

Were there any other reasons that China was so concerned about reciprocity? What then prompted it to withdraw the MFN exemption? This section is to address these questions from a historic perspective.

\section{A. Unequal Treaty System in Colonialism Era}

To offset serious balance of payments problems for the British purchase of tea and silk, Britain (with U.S. support) fought the Opium Wars of the mid19th Century (1839-42 and 1856-60) for the unlimited right to sell opium to the Chinese. ${ }^{93}$ Britain's victory over China in the Opium Wars created an "unequal treaties" system, in which China was forced to grant unilateral MFN status $^{94}$ in the treaties between China and foreign powers including the United States. ${ }^{95}$

The treaties typically stated that:

the contracting parties hereby agree that should at any time the Ta-Tsing Empire grant to any nation, or the merchants or citizens of any nations, any right, privilege, or favor connected either with navigation, commerce, political or other intercourse which is not conferred by this Treaty, such right, privilege, and favor shall at once freely enure to the benefit of the United States, its public officers, merchants, and citizens. ${ }^{96}$

In these unequal treaties, China was required to impose tariffs fixed by treaty obligations without any equivalent tariff concessions, and China did not receive any equivalent grant of MFN from Great Britain, the United States or other foreign powers. " ${ }^{97}$ "This lack of reciprocity attained by the MFN clauses

Richard Guo, Time to Honor China's WTO Commitments: Ministry of Justice Issues Implementing Rules Regarding Foreign Law Firm Administration, CHINA LAW \& PRACTICE (Oct. 2002).

92. See Provisional Regulations On the Setting Up of Offices by Foreign Law Firms Within the Territory of China art. VI [hereinafter Provisional Regulations].

93. See Joseph Gerson, The Debate Over Permanent Normal Trade Relations Treatment With China, available at http://www.afc.org/nero/pesp/chinatrd.htm (last visited Apr. 9, 2000).

94. See ZHAO, supra note 36 , at 2.

95. See Gretchen Harders-Chen, China MFN: A Reaffirmation of Tradition or Regulatory Reform, 5 Minn. J. Global TRADE 381, 390 (1996).

96. Id. citing Treaty of Tientsin, art. LIV, Dec. 21, 1858, Great Britian-China, reprinted in 1 Treaties, Conventions, ETC. BETWẸEn ChinA AND Foreign STATES 390 (2d ed. 1917).

97. See id. 
in the unequal treaties is reflected in China's modern day concern for reciprocity in foreign relations" as discussed below in more detail. ${ }^{98}$

The history of unequal treaties combined with Marxist ideology, viewing trade between developing and industrialized countries primarily as a form of exploration, led Communist China to de-emphasize trade in the twentieth century. ${ }^{99}$ However, China continued to grant MFN status in the 1950 's and 1960's, but only to friendly nations such as Yemen, the Soviet Union, Albania, Mongolia, Korea, and Vietnam. ${ }^{100}$ "In China's history, trade and politics have been interwoven from the earliest times, and may so continue." 101 The use of MFN by China in treaties with its allies illustrates the connection between MFN and politics. ${ }^{102}$ The United States' practice is no exception.

\section{B. United States' Conditional MFN Practice}

Under conditional MFN practices, if country A owes MFN treatment to B, it is then obligated to grant $B$ the same privilege it grants to $C$, but only after B has given A some reciprocal privilege to "pay for it." 103 The United States pursued a "conditional MFN" policy prior to World War I and changed to an unconditional policy in $1923 .{ }^{104}$ However, "there are ample situations which have occurred ... that suggest the possibility that the United States has gradually moved away from its earlier adamant support of MFN and multilateralism toward a more 'pragmatic' approach of dealing with trading partners on a bilateral basis and of 'rewarding friends."' 105

One of the earliest post-1945 departures from MFN by the United States was its exclusion of communist countries from such treatment in $1951 .{ }^{106}$ In the Tokyo Round (1973-1979), the United States also took some steps that departed from unconditional MFN. ${ }^{107}$ The U.S. Congress mandated in the 1974 Trade Act that the United States try to offset the "free-rider" problem, at least for industrial countries, by withholding MFN treatment from certain countries if they did not provide reciprocal advantages as a result of

98. Id. at 393.

99. See id. at 395.

100. See id.

101. Harders-Chen supra note 95 , at 396.

102. See id.

103. See JACKSON, supra note 35 , at 137.

104. See id.

105. Id. at 148.

106. See International Trade Data System, Normal Trade Relations, at http://www.itds.treas.gov/mfn.html (last visited Sept. 15, 2002) [hereinafter Normal Trade Relations]. "In 1951, Congress directed President Harry S. Truman to revoke MFN status to the Soviet Union and other Communist countries." Id.

107. JACKSON, supra note 35, at 146. 
negotiation. ${ }^{108}$ In addition, the United States has refused to give unconditional MFN status to all GATT members in connection with the obligations of three of the Tokyo Round Codes, ${ }^{109}$ out of the same concern about the "free-rider" problem and the need to provide an incentive for countries to enter into the discipline of the Codes. ${ }^{110}$

In trade in services, the United States listed MFN exemption for the licensing of foreign financial service suppliers on the basis of reciprocity, although the exemption is very narrow and applicable only against countries in which United States financial institutions were forced to disinvest on the basis of their nationality. ${ }^{111}$ However, maybe nothing is as controversial as the way the United States has dealt with China, which has generated a great sense of bitterness among the Chinese people whose task for more than a century has been ending the era of national humiliation. ${ }^{112}$

A key legislative action Congress faced before China became a WTO member was whether to remove China from coverage under Title IV of the Trade Act of 1974. ${ }^{113}$ Title IV Section 401 of the Trade Act of $1974^{114}$ requires the President to deny MFN to products from a number of countries, including China. ${ }^{115}$

Section 402, better known as the 'Jackson-Vanik
Amendment,' permits a one-year exception when the
President determines that a nation substantially complies with
certain freedom of emigration objectives. The President can
recommend renewal of these waivers for successive twelve-
month periods if he determines that further extensions will
substantially promote these objectives. ${ }^{16}$

Far from the original intent of the 1974 Trade Bill, Jackson-Vanik has changed into an annual Congressional review of China on issues such as human rights, national security, Tibet, Taiwan, environmental concerns, and

108. See id.

109. See id. The Subsidies-Countervailing Duty Code (interpreting arts. 6, 16 and 23 of GATT), the Technical "Standard" Code and the Government Procurement Code. See also Trading Into the Future, supra note 11, at 12.

110. See JACKSON, supra note 35, at 146. See also ZHAO, supra note 36, at 48-49.

111. See Mattoo, supra note 33, at 14. The United States withdrew its MFN exemptions at the end of the Uruguay Round when it was decided that the operation of Article II GATT would be suspended for the duration of the extended negotiations. See id. at 33 n.43.

112. See Gerson, supra note 93.

113. See United States General accounting Office, China Trade: WTO MEMBERSHIP AND MOST-FAVORED NATION STATUS, GAO/T-NSIAD-98-209 9 (June 1998) [hereinafter GAO 1998].

114. See Trade Act of 1994, 19 U.S.C. $\$ \$ 2431-2439$ (1994).

115. See GAO 1998, supra note 113, at 9 .

116. Id. 
labor practices-to name a few. ${ }^{117}$ It is widely agreed that the annual debate has done little or nothing to improve human rights and labor standards in China. Instead it makes the bilateral relations unnecessarily confrontational. ${ }^{118}$ Although pursuant to the "annual waivers," China had been granted "MFN" status ${ }^{119}$ since 1980 to, most recently, June 3, 1999, ${ }^{120}$ the Chinese understandably perceive the United States' yearly debate over MFN as an insult. ${ }^{121}$

\section{China's Foreign Trade Law}

"The Foreign Trade Law was enacted at the same time China and the United States were battling over U.S. MFN status." ${ }^{122}$ The Foreign Trade Law sets forth China's general principles of foreign trade, which emphasize equality and mutual benefit. ${ }^{123}$

The recurrent Chinese concern over reciprocity appears explicitly in the MFN clause of the Foreign Trade Law: ${ }^{124}$ "The People's Republic of China grants [MFN] treatment or national treatment in the field of foreign trade to opposite concluding or acceding parties in accordance with international treaties or agreements concluded or acceded to, or on the basis of the principles of mutual benefit and reciprocity." 25 "By viewing application of the U.S. MFN principle as a personal insult, China was inclined to view the nondiscrimination principle of its own MFN clause as a vehicle for retaliation." 26 "Article 7 of the Foreign Trade Law reserves to China the ability to retaliate against any country not willing to abide by the Chinese MFN principle."127 "China threatened to retaliate under the authority of Article 7 as soon as the United States invoked sanctions against China in 1995." 128

117. See Gerson, supra note 93.

118. See id.

119. See United States General ACCOUNTING OFFice, ChINA's Membership Status AND NORMAL TRADE RELATIONS ISSUES, GAO/NSAID/00-94 4 n.l (March 2000) [hereinafter GAO 2000]. "In July 1998, the term 'normal trade relations' replaced the term 'most-favorednation' in U.S. law." Id.

120. See Press Release, Office of the Press Secretary, To Extend Nondiscriminatory Treatment to the Products of the People's Republic of China by the President of the United States of America a Proclamation (Dec. 27, 2001), available at http://www.whitehouse. gov/news/releases/2001/12/print/20011227-1.html (last visited Sept. 16, 2002).

121. See Harders-Chen, supra note 95 , at 405 .

122. Id. at 399-400.

123. See id. at 407 (citing Foreign Trade Law of the People's Republic of China, Act of May 12, 1994, art. 5, 8 CHINA L. \& PRAC. 20, 20 (1994)).

124. See id.

125. See id. at 407 (citing Foreign Trade Law, supra note 123, art. 6).

126. See id. at 405.

127. Harders-Chen, supra note 95 , at 400.

128. See id. at 402. 
China is not the only country to retain the ability to implement retaliatory actions against other nations for failing to abide by nondiscrimination principles in trade. ${ }^{129}$ U.S. policies under Section 301 of the Foreign Trade Law falls into same category. ${ }^{130}$ "Widespread usage of domestic retaliatory actions outside the WTO may undermine the effectiveness of the GATT."131

\section{Permanent Normal Trade Relations (PNPR)}

China's prospective WTO membership raised a critical issue about how the United States will handle China's MFN status under U.S. law. The U.S. government realized that the temporary (conditional) MFN under JacksonVanik would conflict with the WTO obligation to provide unconditional MFN to WTO members on a permanent basis, ${ }^{132}$ and the United States would have to either remove China from Title IV's coverage or invoke the "nonapplication clause" of WTO Article XIII. ${ }^{133}$

Article XIII of the agreement establishing the WTO permits either a WTO member or an incoming member to refuse to apply WTO commitments to one another. ${ }^{134}$ In case of the United States invoking "non-application" against China, the Sino-U.S. business dealings would continue under the 1979 U.S.-China bilateral agreement under which China is obligated to provide the U.S. MFN treatment, but only in the areas mentioned. ${ }^{135}$

Therefore, since the 1979 agreement (which provides for "reciprocal" MFN status ${ }^{136}$ between the two countries) does not establish clear MFN obligations for services and service suppliers, ${ }^{137}$ the net effect would be that American lawyers would not be entitled to any benefits China would have offered to lawyers from other WTO members. Furthermore, none of the bilateral agreements between the United States and China provide for binding multilateral dispute settlement, as do the WTO agreements. Thus, in the event of non-application, the United States would have to continue to enforce trade violations under U.S. law, ${ }^{138}$ and "China would certainly reciprocate."139

129. See id. at 411-12.

130. See id. at 412.

131. Id.

132. See GAO 1998, supra note 113 , at 9.

133. See GAO 2000, supra note 119 , at 16 .

134. See id. at 16-17.

135. See GAO 1998, supra note 113, at 2.

136. See id.

137. See id.

138. See GAO 2000, supra note 119 , at 18.

139. China, the WTO and Permanent Normal Trade Relations, WASHINGTONSTATECHINA RELATIONS COUNCIL (Jan. 2000), available at http://www.wcit.org/topics/china/chi_update _1_00_htm (last visited Sept. 15, 2002). 
It is in the interest of the United States, including American law firms, to grant China permanent MFN. "Since the Jackson-Vanik amendment provision only allows a 1 year waiver of Title IV restrictions and Congress can disapprove the waiver, the [Clinton] administration plans to ask Congress to enact legislation that would remove China from title IV's coverage." ${ }^{40}$ In October 2000, the legislation was passed providing the President with discretionary authority to grant permanent MFN, now known as normal trade relations, to China after certifying that the terms and conditions for the accession of the People's Republic of China to the WTO were at least equivalent to those agreed between the United States and China on November 15, 1999. ${ }^{141}$

On December 27, 2001, President Bush announced that Chapter 1 of Title IV of the Trade Act should no longer apply to China and nondiscriminatory treatment (normal trade relations treatment) shall be extended to the products of China, effective January 1, 2002. ${ }^{142}$ The name of MFN status was changed to "Normal Trade Relations" (NTR) status because it was believed that the term MFN was deceiving. ${ }^{143}$ "Under NTR both parties agree not to extend to any third party nation any trade preferences that are more favorable than those available under the agreement concluded between them unless they simultaneously make the same provisions available to each other." 144

However, there is at least one other explanation for the name change as applied to China-it "was getting hard to stomach redesignating the Communist Chinese slave state as 'most favored' every year." 145 Whatever the real reason, thanks to the December 27 Executive Order, China formally "graduated" from the Jackson-Vanik. ${ }^{146}$ Although the Congressional vote on

140. GAO 1998, supra note 113 , at 9 .

141. See 19 U.S.C. § 2434 (1994).

142. See Press Release, Office of the Press Secretary, To Extend Nondiscriminatory Treatment to the Products of the People's Republic of China by the President of the United States of America a Proclamation (Dec. 27, 2001), available at http://www.whitehouse.gov/ news/releases/2001/12/print/2001 1227-1.html (last visited Sept. 16, 2002).

143. See Normal Trade Relations, supra note 106. Normal Trade Relations are actually the norm in bilateral trade relationships between countries and most nations have this trade status except for a handful of rogue nations that have been refused this normal trade relationship. See id.

144. Id.

145. David W. Neuendorf, Make Normal Trade Relations Normal (2000), available at http://www.seidata.com/ neusys/colm0129.html (last visited Sept. 1, 2002).

146. See Press Statement, U.S. Department of State, Office of the Spokesman, Presidential Proclamation on Trade Relations with Georgia (Jan. 3, 2001), available at http://secretary.state.gov/www/briefings/statements/2001/ps010103.html (last visited Sept. 15, 2002). The process of a country being removed from the coverage of Title IV of the Trade Act of 1974 is known as "graduation." See id. 
PNTR would not have affected China's accession in the first place, ${ }^{147}$ it is considered a good gesture for China and the United States to "develop healthy and stable economic and trade ties on an equal and mutually-beneficial footing."

Besides, it became more and more clear that China would soon obtain the WTO membership. "Once China becomes a member of the WTO, the concerns over reciprocity may subside because China has achieved equal footing with other contracting parties. GATT MFN allows some flexibility in equal treatment by allowing countries to bargain for preferences, thus supporting an element of reciprocity in tariff negotiations." 149 This may have helped China overcome its MFN syndrome. From reciprocity-based-MFN to unconditional "MFN," the history of foreign law firms in making inroads into China is just a vivid snapshot of this historic transition.

\section{E. The Right of Establishment of Foreign Law Firms in China}

\section{Historical Perspective}

Where business goes, lawyers follow. With the initiation of reform and open-door policies, foreign investment in China blossomed and created great demand for legal services. ${ }^{150}$ However, China's legal profession did not arrive on the social scene until August 26, 1980, when the Fifteenth Session of the Standing Committee of the Fifth National People's Congress passed the "Tentative Regulations on Lawyers in People's Republic of China," which laid the foundation for development of the legal profession in China. ${ }^{151}$ Even then, it was still impossible for foreign lawyers to obtain official access to China, not to mention permanent presence, because lawyers were defined as "state legal workers"152 under the "Tentative Regulations" and the legal profession was rather politically delicate in nature. ${ }^{153}$

Nevertheless, foreign law firms still managed to make inroads into China in various forms. In August 1979, as counsel to its then client Amoco,

147. See China, the WTO and Permanent Normal Trade Relations, supra note 149. Congressional approval is not required for China's membership in the WTO. See id. With or without a PNTR under the U.S. law, China would still become a full member of the WTO once it completes the rounds of diplomatic negotiations with WTO member states. See id. But in the latter case, almost certainly the United States had to apply non-application, China would have the right under WTO rules to extend its WTO commitments to all of its trading partners, except the United States. See id.

148. U.S. Passes Bill on China's PNTR Status (Febr. 25, 2000), available at http://www.chinadaily.net/highlights/docs/2001-04-30/2987.html (last visited Sept. 15, 2002).

149. Harders-Chen, supra note 95 , at 407.

150. Xiao, supra note 83.

151. See generally Luo, supra note 5 , at 1.

152. Id. at 10.

153. See Gao, supra note 10. 
Coudert Brothers opened its Beijing office where it also carried out business under its own name. ${ }^{154}$ It is believed to be the first-ever foreign law firm to provide legal service within the jurisdiction of China. ${ }^{155}$ Vinson \& Elkins operated on a visiting lawyer basis through a Beijing local office before it was officially issued license in March 1999. ${ }^{156}$

Working around the strict bans on setting up branch offices in China, many other firms showed up in various identities - consulting firms or business vehicles as permitted by the Ministry of Foreign Economic Relations and Trade (MOFER), the predecessor of today's Ministry of Foreign Trade and Economic Cooperation (MOFTEC). ${ }^{157}$ The Chinese government obviously felt the pinch and started to research the possibilities of licensing foreign law firms. Delegations were sent to Singapore, Hong Kong, and European countries in $1986 .{ }^{158}$ Unfortunately, the June 4, 1989, student protest in Tiananmen Squire and the ensuing political firestorm brought all the on-going preparation to a halt. Foreign investment shrank and the law firms with already established consulting offices in China started to withdraw from the China market. ${ }^{159}$

It was only three years later, on July 1, 1992, when the State Council formally authorized the Ministry of Justice ("MoJ") to start the licensing of foreign law firms on a trial basis. ${ }^{160}$ The "beauty contest" turned out so fierce that some firms could no longer wait for an official approval and were "sending lawyers to work out of hotel suites on a project-by-project basis, or opening up full-blown unapproved offices." Adams (France), Denton Hall (England), Lovell White Durrant (England), Licasiri \& Co (Hong Kong), and eight other firms were among the first lucky law firms who were officially granted the right of establishment. ${ }^{162}$ As of September 6, 2001, ninety-four foreign law firms (in addition to twenty-five from Hong Kong) have obtained permissions from MoJ and registered with the State Administration for Industry and Commerce ("SAIC") or its local

154. Virginia Kays VeEnswojk, COUdERT Brothers: A Legacy in LaW, THE History OF AMERICA's FIRST INTERNATIONAL LAW FIRM (1853 - 1993) 401 (1994).

155. See id.

156. Interview with Hongming Xiao, former division chief at the Lawyers Department in the Ministry of Justice of China, in New York, USA (Oct. 1, 2000).

157. Market Analysis: China (Sept. 2001). For instance, Paul Weiss, Graham \& James and Dewey Ballantine first emerged on stage as consulting firms in Beijing and Shanghai respectively. See Xiao, supra note 83.

158. See Interview with Hongming Xiao, supra note 156.

159. See generally McCollam, supra note 7.

160. See id.

161. Yujie Gu, Entering The Chinese Legal Market: A Guide For American Lawyers Interested In Practicing Law In China, 48 DRAKE L. REV. 173, 199 (1999).

162. See The Joint Announcement of Ministry of Justice and State Administration for Industry and Commerce(Sept. 6, 2001), available at http:/www.civillaw.com.cn/typical/Law Centerqt/Content.asp?No=881 (last visited Nov. 3, 2002) [hereinafter Joint Announcement]. 
branches. ${ }^{163}$ They spouted in Beijing (52), Shanghai (48), Guangzhou (11), Shenzhen (2), Suzhou (1), Qingdao (1), Tianjin (1), Dalian (1), Fuzhou (1) and Chengdu (1) respectively. ${ }^{164}$

The experimental licensing program has entered into its tenth year. Lacking clear guidelines, the "historically arduous"165 licensing process has been, by and large, subject to MoJ's discretion. There seems to be little pattern in the awarding of licenses. ${ }^{166}$ The practice has aroused many controversies and has been attacked on the basis of transparency ${ }^{167}$ Law firms desperate to secure a license have to learn from others' experience as a more reliable guideline. A law review article summarized "building relations with" and "doing quite a few favors for government officials" as the keys to the success of a medium-sized U.S. firm (Altheimer \& Gray). ${ }^{168}$

\section{The Current Regulatory Regime: Reciprocity in Practice}

The major legislative piece on the regulation of foreign law firms has until very recently been the "Provisional Regulations on the Setting Up of Offices by Foreign Law Firms Within the Territory of China," (hereinafter "Provisional Regulations"). ${ }^{169}$ MoJ also released a series of administrative regulations including the "Operational Procedures On the Review, Approval and Administration of Representative Offices of Foreign Law Firms"170 (hereinafter the "Operational Procedures"), the "Detailed Regulations on Several matters relating to the Review, Approval and Administration of Representative Offices of Foreign Law Firms"171 (hereinafter the "Detailed Regulations"), and the "Notice Regarding Matters With Regard to Foreign Law Firms Applying to Set Up Offices in China" (hereinafter the "Notice"). ${ }^{172}$

\section{See id.}

164. See id.

165. Livingston, supra note 8.

166. See Information Paper, supra note 1, at 6. According to an MOFTEC (instead of MoJ) official, the approval issued by the $\mathrm{MoJ}$ is mainly based upon the following considerations: (1) the size, strength and track record of the applicant firm in the country of origin or over the world; (2) the volume of business in the PRC handled by the applicant firm; (3) the relationship between the applicant firm's country of origin and the PRC; and (4) the principle of reciprocity, i.e., whether the applicant firm's country of origin would allow foreign law firms to set up offices in that country. See id.

167. McCollam, supra note 7.

168. See Gu, supra note 161 , at 207-209.

169. See Provisional Regulations, supra note 92. It was co-issued by the Ministry of Justice and the State Administration for Industry and Commerce on May 26, 1992, coming into force on July 1, 1992. See id.

170. Waiguo Lushi Shiwusuo Banshichu Shenpi Guanli Gong Zuo Cao Zuo Guicheng, Ministry of Justice (May 26, 1992) [hereinafter Operational Procedures].

171. Guanyu Waiguo Lushi Shiwusuo Banshichu Shenpi Guanli Jige Wenti De Juti Guiding, Ministry of Justice (Mar. 2, 1993) [Detailed Regulations].

172. Guanyu Waiguo Lushi Shiwusuo Zaihua Sheli Banshichu Youguanshiyi De Tongzhi, Ministry of Justice (Oct. 30, 1992) [hereinafter Notice]. 
The regulations, all centered around Mode 3 of legal services, i.e. commercial presence, laid down a Licensing ("Pi Zhun"), Registration ("Deng Ji Zhu Ce") and Annual Report system for the foreign law firms exploring ways to set up outposts in China. ${ }^{173}$ Under the system, a foreign law firm must obtain a license from MoJ before opening an office. ${ }^{174}$ The awarding of licenses was governed by principle of reciprocity, i.e., China will grant the right of establishment only to those firms whose home country grants Chinese firms the same right. ${ }^{175}$

To substantiate the "reciprocity" principle of the Provisional Regulations, the Detailed Regulations required a foreign law firm provide documents certifying that its home country permits establishment of liaison offices by law firms from other countries including China. ${ }^{176}$ Furthermore, the aspiring law firm must not only possess the competence in bringing in foreign investment but also has been friendly to China. ${ }^{177}$ This is consistent with China's historical treaties granting MFN in the 1950's and 1060's to its allies. ${ }^{178}$

MoJ is the government agency with primary jurisdiction over administration, supervision and inspection of foreign law firms in setting up representative offices. ${ }^{179} \mathrm{MoJ}$ authorizes its local Departments/Bureaus, at the level of the provinces, autonomous regions and cities directly under the Central Government where the representative offices are to be located, to administer, supervise and inspect the representative offices as going concerns. ${ }^{180}$ The MoJ had levied certain restrictions on foreign law firms:

\section{a. Legal Forms}

In terms of the legal forms, foreign law firms may only set up "Representative Office(s)" in China, ${ }^{181}$ meaning that the Representative Offices are not legal persons and their tax obligations and indebtedness shall

173. See discussion, infra Part IV.

174. See Provisional Regulations, supra note 92, art. II.

175. See id. art. VI.

176. See Detailed Regulations, supra note 171, art. III "Application Materials," Item 6.

177. See id. art. V(1).

178. See discussion infra Part III(A).

179. See Provisional Regulations, supra note 92, art. XIX. Before a Representative Office can be set up, it must also be registered with the State Administration of Industry and Commerce (SAIC) (art. 3). See id. art. II. The name of a Representative Office shall be the combination of the Alma Mater firm and the Chinese city where the office is located. See id. art. X. For instance, Allen \& Overy Beijing office is registered as llen \& Overy, Beijing Office (England). Moreover, the Representative Offices must, before January 31 of each year, submit a written report to the local Department/ Bureau of Justice, in triplicate and in Chinese, highlighting its business, revenue, expenses and tax paid in the previous year. See id. art. XXII.

180. See id. art. XIX.

181. See id. art. II. 
be borne directly by the foreign law firms. ${ }^{182}$ Foreign law firms cannot engage in legal services under the disguised form of "consulting firms" or "commercial firms" to sidestep the license and registration requirements. ${ }^{183}$

\section{b. Practice Areas}

The most rigid limitations are on practice areas. Representative Offices are prohibited from interpreting Chinese law, representing clients on Chinese law matters or engaging in other activities which are precluded from foreigners, ${ }^{184}$ although they may accept assignments from Chinese clients or Chinese law firms for legal matters related to the home country or any third country where they are officially qualified, and they can act as agents for foreign clients and in turn hire Chinese law firms to handle legal matters in China. ${ }^{185}$

\section{c. Local Hiring}

Representative Offices are prohibited from hiring Chinese lawyers. ${ }^{186}$ Under the Notice, it seems that foreign law firms are prohibited from hiring not only Chinese "licensed" lawyers, but also any person who has passed the National Bar Examination ${ }^{187}$ and is thus domestically "qualified."188 Notwithstanding the prohibition against hiring Chinese lawyers, in practice Representative Offices commonly recruit law graduates, many of who have passed the national bar and thus are qualified under Chinese law, as legal assistants or legal secretaries. ${ }^{189}$ Even licensed Chinese lawyers often show up on the payrolls, but theoretically they have to forfeit their right to practice Chinese law. ${ }^{190}$

182. See id. art. XIV.

183. See id. art. III.

184. See id. art. XVI.

185. See Provisional Regulations, supra note 92, art. XV.

186. See id. art. XVII. In the author's opinion, it is unclear what exactly the term "Chinese lawyers" mean. The "Notice" and "Detailed Regulation" evidenced the consciousness on the part of the drafters of the distinction between a "Chinese licensed lawyer" and a "Chinese citizen with qualification to practice law." According to Article 5 of the "PRC Lawyers' Law," one has to be both qualified and licensed before he can practice law. The usual way to get qualified is to pass the National Bar Exam, and a license is issued only following an administrative review.

187. See Press Release, Establishment and Enforcement of the National Uniform Judicial Examination (Feb. 7, 2002), available at http:/www.china.org.cn/e-news/news02-02-7.htm(last visited Sept. 16, 2002). The national bar examination, which was put in place in 1986, is now incorporated into the national judicial qualification examination. See id.

188. See Notice, supra note 172 , art. $\mathrm{LX}(\mathrm{a})$.

189. It is the author's opinion that this becomes a common method of localization by the Representative Offices in staffing their Chinese deals.

190. See discussion, infra Part $\mathrm{E}(\mathrm{b})(7)$. In China, licenses are technically granted to law firms rather than individual lawyers. 


\section{d. Geographic Limitation}

The pilot program of licensing foreign law firms is geographically limited. At first only in Beijing, Shanghai, Guangzhou, Shenzhen and Hainan ${ }^{191}$ could Representative Offices be set up. ${ }^{192}$

\section{e. Quantitative Limitation}

Known as the "One Firm, One Office" rule, the rule mandates that each foreign law firm may only have one Representative Office in China. ${ }^{193}$ Legal services may not be provided under the camouflage of another name, such as "consulting firm." 94

\section{Qualification Requirements}

As a practical matter, although there is no written provision, the approval authority has applied certain "seasoning requirements" in licensing foreign law firms. ${ }^{195}$ For example, the chief representative and others must have at least three years of practicing experience, and no representative may have been subject to professional discipline at their local bar. ${ }^{196}$ Furthermore, the chief representative must be admitted in the country where the law firm is headquartered. ${ }^{197}$

191. Detailed Regulations, supra note 171, art. V, 1(3). Hainan (province) is replaced by the City of Haikou. See id.

192. See 1997 Schedule, supra note 85 . In the November 1997 version of China schedule of specific commitments and the 1999 U.S.-China Market Access Agreement, Dalian, Qingdao, Ningbo, Yantai, Tianjin, Suzhou, Xiamen, Zhuhai, Hankzhou, Fuzhou, Wuhan, Chengdu, Shenyang and Kunming were added in the list, and Haikou substituted Hainan. See id.

193. See Xiao, supra note 83.

194. See id.

195. See Market Analysis, supra note 157. Foreign lawyers must be experienced in their home jurisdiction before they can practice, as registered foreign lawyers, in China. See id.

196. See id.

197. See Gu, supra note 161 , at 201-02 n.306. This is a rather peculiar provision. However, one European law firm which, thanks to the very provision, was forced to replace an American lawyer as its chief representative. See id. This requirement was later changed to require a chief representative to be a partner of a law firm of a WTO Member. See WORLD Trade Organisation, Protocol on the Accession of the People Republic of China, Annex IX, Schedule of Specific Commitments on Services, WT/ACC/CHN/49/Add.2 [hereafter Final Schedule]. 


\section{f. Disciplinary Rules ${ }^{198}$}

For any violation of the "Provisional Regulations," MoJ or its authorized local agencies may impose a disciplinary warning, or either suspend or revoke a license. Similarly, the SAIC and its local agencies may impose fines, confiscate illegal gains or annul the registration. ${ }^{199}$ For instance, both Coudert Brother and Baker \& Mackenzie received a violation notice and had to close their "illegal" Shanghai shops in $1995^{200}$ for violating the "onecity rule" discussed below. ${ }^{201}$

The lack of transparency of Provisional Regulations inevitably led to misunderstanding. For instance, in 1996, to ascertain the effect of the tentative licensing program, Beijing Bureau of Justice conducted a "feasibility study" of Representative Offices' business performance. ${ }^{202}$ The study elicited, among other things, certain information about the clients of these Representative Offices. The U.S. lawyers, constrained by strict ethical canons, were extremely concerned that their lawyer-client privilege had been jeopardized. ${ }^{203}$ Rumors loomed large that $\mathrm{MoJ}$ was to mandate the disclosure of a broad range of confidential information including the clients' names, the location and nature of the clients' projects and the amount of investment behind the projects. ${ }^{204}$

MoJ later clarified that no clients' names were to be disclosed. However, the exaggerated response of U.S. lawyers frustrated MoJ as well. As a matter of fact, the notion of attorney-client privilege is by no means an international one. For instance, the International Court of Justice held in Am \& S Europe Ltd. v. Commission that a U.S. lawyer representing an E.U. client might be forced to produce an otherwise privileged document to the client government. ${ }^{205}$ The U.S. lawyer, according to the holding, could not claim attorney-client privilege since the privilege applies only to lawyers governed by professional ethics within the E.U. ${ }^{206}$

198. See Provisional Regulations, supra note 92, art. XXIII.

199. See id.

200. See $\mathrm{Gu}$, supra note 161 , at 200.

201. See id. Interestingly, while Clifford Chance allegedly used its influence with the MoJ to have Baker's second office under the disguise of a "consulting office" in Shanghai shut down, Clifford Chance, licensed to be in Shanghai, also technically violated the one-city rule when it merged with Germany's Punder Volhard Weber \& Axster, which has an office in Beijing. See McCollam, supra note 7.

202. See Gu, supra note 161 , at 200.

203. See Cynthia Losure Baraban, Inspiring Global Professionalism: Challenges and Opportunities for American lawyers in China, 73 IND. L.J. 1247, 1247 n.2 (1998).

204. See id. at 1247.

205. See Burr, supra note 13 , at 680.

206. See id. 
Any similar disputes after China's entry into WTO might soon be subject to WTO dispute panels. ${ }^{207}$ As proposed, a domestic regulation, like the one in our case, "relating to qualification requirements and procedures, technical standards and licensing requirements, ${ }^{208}$ once challenged, may have to meet certain necessity tests. ${ }^{209}$ The regulators may have to prove that the objective of the challenged regulation is "legitimate" according to WTO rules and that the regulation is the "least trade restrictive." certain trade experts, instead of "democratically-elected governments," to decide what is "legitimate" and what is "unnecessarily restrictive," and this worries people. ${ }^{211}$

There is an open question with respect to individual foreign lawyers' capacity to enter into China's legal market. It is noticeable that Chinese licensing is firm-based, which means that individuals who pass the national bar exam are qualified, but must still acquire sponsorship from a firm to receive their licenses. ${ }^{212}$

The Provisional Regulations are reluctant to recognize these foreign lawyers' "lawyer" status. Rather, the Staff of Representative Offices is referred to as "members," reflecting the regulator's consciousness of the national characteristics of the legal profession and the built-in sensitivity of the socialist legal system. ${ }^{213}$ There is also no "Foreign Legal Consultant" (FLC) system present. Therefore, an individual U.S. lawyer is simply not eligible to practice in China. A U.S. lawyer can, however, provide legal services (exclusive of Chinese law) from the United States into China or within the United States to a Chinese customer because China did not schedule mode 1, "Cross-border," and mode 2, "consumption abroad," of trade in legal services. ${ }^{214}$ And, of course, solo practitioners can penetrate by first setting up a law firm in the United States and then initiating the application on the firm's behalf. ${ }^{215}$

207. See Woodroffe, supra note 15 , at 26 . The Working Party on Domestic Regulation is currently discussing certain proposals under Article VI:4 of GATS. See id. "If such proposals were accepted, they would increase the reach of GATS right into the heart of government decision-making." Id.

208. GATS, supra note 24 , art. VI(4).

209. See Woodroffe, supra note 15 , at 27.

210. See id.

211. See id. at 40.

212. See The Lawyer's Law, arts. V, VIII, X, XIV and XV, available at http://www. civillaw.com.cn/typical/LawCenterqt/Content.asp?No=1318 (last visited Sept. 29, 2002).

213. See Provisional Regulations, supra note 92. Throughout the Provisional Regulations, the staff of a Representative Office is referred to as either "Chief Representative" or "members," but never as "lawyers." See id.

214. See Final Schedule, supra note 197. The entries for mode 1 and 2 read "NONE" in the Final Schedule, which means that there are no limitations on market access or national treatment in cross-border supply and consumption abroad. See id.

215. For instance, Paragon Law Offices Beijing Office (USA) seems to support this assertion. See Joint Announcement, supra note 162. 
Since GATS applies to four different modes of supplying services, extending equal treatment to services which are "like" one another means that Chinese regulators cannot discriminate against firms which supply legal services in these different ways. ${ }^{216}$

\section{How ACCESSIBLE IS THE ChINESE Legal MARKET Now?}

\section{A. China's Commitments in Legal Services}

In November 1999, the United States and China reached an agreement on China's commitment to open its services sector. China agreed to open nine of its twelve service sectors-including legal services-to foreign service providers, though with some specified limitations. ${ }^{217}$

The negotiation between China and the United States was widely considered as the most significant obstacle to China membership. ${ }^{218}$ After thirteen years of marathon negotiation on China's WTO membership, U.S. Trade Representative, Charlene Barshefsky, and Chinese Minister of MOFTEC, Shi Guang Sheng, finally signed the Agreement On Market Access (hereafter the "U.S.-China Pact" or "Market Access Agreement") on November 15, 1999. ${ }^{219}$ The Pact, combined with the signing of another trade pact with the European Union in May 2000, removed the greatest hurdles to

216. See generally Woodroffe, supra note 15 , at 21.

217. See GAO 2000, supra note 119.

218. See World TRade Organization, How to Become a Member of the WTO, at http://www.wto.org/English/thewto_e/acc_e/access_e.htm (last visited Oct. 26, 2002). It is necessary to pause here to familiarize the reader with the basic WTO accession process. After receiving an application to accede to the WTO under Article XII, a Working Party is established composed of any interested member. See id. Based upon a Memorandum submitted by the applicant, the Working Party conducts a fact-finding process to examine the foreign trade regime of the applicant. See id. At about the same time, the applicant commences bilateral market access negotiations on goods, services and other specific terms of accession with members of the Working Party who have made the requests, the resulting market-access commitments of which are to become the payment for the entry ticket into the WTO of the acceding government. See id. Following the conclusion of the bilateral negotiations, the Working Party prepares a raft Report together with a raft Protocol of Accession containing the terms of accessions agreed to by the applicant and the members of the Working Party. See id. Annexed as part of the Draft Protocol are the Schedule of Specific Commitments of Services, if any, and the chedule of Concessions and Commitments on Goods. See id. Having been so multilateralized, the bilateral agreements, including the raft Report and raft Protocol and Schedules, are then finalized into a package and submitted to the WTO General Council/ Ministerial Conference for approval. See id. The rotocol of Accession becomes effective upon approval and the applicant becomes a WTO member thirty days after its acceptance of the Protocol. See id. .

219. See the text of the Agreement, available at http://www.uschina.org/public/wto/ factsheets/ (Feb. 7, 2000) (last visited Nov. 3, 2002). 
China's accession. ${ }^{220}$ The Doha Ministerial Conference adopted the text of China's Accession Agreement in November 2001. The final Schedule of Specific Commitments on Services, ${ }^{221}$ including legal services, is annexed to the Protocol of Accession of China. ${ }^{222}$

Because of the ongoing nature of the multilateral trade negotiations, a series of bartering processes were or have been reflected in the Final Schedule. ${ }^{223}$ For instance, the Sino-Europe trade pact, at the lobbying of the American law firm Paul Weiss, did away-albeit for a limited period-with the U.S.-China pact requirement that a foreign law firm's China office must be headed by a partner of the firm. ${ }^{224}$ This rule, after the tentative withdrawal in the Sino-Europe pact, revisits China's Final Schedule. ${ }^{225}$

Essentially, China committed to lift all geographic limitations and quantitative limitations within one year after China's accession to the WTO, i.e., before December 11, 2002. ${ }^{226}$ Before then, a foreign law firm could only establish one representative office in China, and in only one of the nineteen cities including Beijing, Shanghai, Guangzhou, Shenzhen, Haikou, Dalian, Qingdao, Ningbo, Yantai, Tianjin, Suzhou, Xiamen, Zhuhai, Hangzhou, Fuzhou, Wuhan, Chengdu, Shenyang, and Kunming. ${ }^{227}$

220. See Business Community Welcomes Release of Trade Agreement Text, available at http://www.uschina.org/public/wto/b4ct/release.html (Mar. 14, 2000) (last visited Nov. 3, 2002). As far as the legal service is concerned, the U.S.-China pact expressly excludes foreign law furms from Chinese law practice. See id. It also preserves most of the limitations in China 1997 draft of GATS Schedule, including experience requirements and residence requirements. See $i d$. China promised to lift the ban on geographic limitations and quantitative limitations, e.g., nineteen city and one office rule, within one year of China accession. See id. Business scope is almost as restrictive as the 1997 draft, except that the pact permits foreign law firms to have ong-term entrustment relations with Chinese firms, although partnership with local firms is still strictly prohibited. See id. The Market Access Agreement was sent to the WTO Secretariat for incorporation into the multilateral aspects of China accession to the WTO. See id. To facilitate U.S. Congressional approval, the Agreement was publicly released, on the joint decision of the United States and Chinese governments, on March 14, 2000. See id. Ordinarily, bilateral agreements on WTO accession are not made public until all other WTO members have finished their bilateral negotiations with an aspiring member. See id.

221. See Final Schedule, supra note 197.

222. See WORLD TRADE ORGANIZATION, Report of the Working Party on the Accession of China, 343, WT/ACC/CHN/49.

223. See discussion, infra Section II(B) regarding the "multilateral negotiation approach."

224. See Loomis, supra note 2. After the United States and China reached the historic agreement, American lawyers complained that, due to the mandated Partner-as-head rule contained therein, the legal service was actually put under greater restrictions. See id.

225. See Final Schedule, supra note 197; infra pt. IV(A)(c), regarding "experience requirement."

226. See Final Schedule, supra note 197; infra pt. I(A)(a), Limitations on Market Access 3.

227. See Interview with Hongming Xiao, supra note 156. Under 1997 Schedule, the total number of Representative Offices in China should not exceed 80. See id. However, this quota threshold, although not officially outlawed, has been dismantled. See id. 
Foreign Representative Offices may now enter into contracts to maintain "long-term entrustment relations" with Chinese law firms for legal affairs, ${ }^{228}$ as was first achieved in the 1999 U.S.-China Trade Pact. ${ }^{229}$ Such entrustment would allow the foreign representative offices to directly instruct lawyers in the entrusted Chinese law firm, as agreed between both parties. ${ }^{230}$ Furthermore, they are allowed to provide information on the "impact of the Chinese legal environment."231

According to the Final Schedule, China offers to give legal service providers from all WTO members the specified market access and national treatment, subject only to certain limitations. For example, "legal form limitation," "business scope limitation," and "experience requirements" are market access limitations; "residence requirement" and "restriction on local hiring" are national treatment limitations; and "presence of natural persons" is both. ${ }^{232}$

\section{Legal Form Limitation}

Foreign law firms may provide legal services in China only in the form of Representative Offices, ${ }^{233}$ i.e., they can not incorporate in forms of limited liability companies. Under GATS, the government can not maintain such market access restriction unless so specified in the schedule. ${ }^{234}$ "Countries often justify the restriction of incorporation on public policy grounds, and in particular, to ensure that professionals do not limit their professional responsibilities and liabilities."235

\section{Business Scope}

Chinese law practice by foreign firms will still be prohibited. ${ }^{236}$ For Chinese legal affairs, foreign representative offices may entrust only Chinese law firms to deal with Chinese legal affairs on behalf of foreign clients. ${ }^{237}$ Therefore, a foreign law firm's representative office may only provide legal services on the law of its home country, international law and the law of a

228. See id.

229. The long term entrustment contracts may provide for "close working relationships" with Chinese firms. See U.S. - China Trade Pact, at http://www.uschina.org/public/wto/ factsheets/professional.html (last visited Nov. 9, 2002).

230. See Final Schedule, supra note 197; pt. II(A)(a), Limitations on Market Access.

231. Id. at Limitations on Market Access, $3 \mathrm{e}$.

232. See id. at Limitations on Market Access, 3-4. and Limitations on National Treatment $3-4$.

233. See id. at Limitations on Market Access, 3.

234. See GATS, supra note 24, art. XVI(2)(e).

235. Background Note, supra note 60, 132.

236. See Final Schedule, supra note 197, at Limitation on National Treatment, 3a.

237. See id. at Limitations on Market Access, 3c. 
third country where the lawyers of the representative office are qualified. ${ }^{238}$ The nationality-based business limitation ensures that only Chinese nationals can practice domestic law. According to the Secretariat on Legal Services, nationality requirements in legal services are actually quite common, especially for notarial services, representation services (in all fields of law) and other sectors which involve "public function." 39

Socialist China's stake is especially high. Despite the reclassification of Chinese lawyers from "state legal worker" to "legal service provider" under the 1996 Lawyers' Law, ${ }^{240}$ the legal profession per se is still rather delicate and politically sensitive. ${ }^{241}$

\section{Experience Requirements}

The chief representative shall be a partner, or equivalent, ${ }^{242}$ of a foreign law firm with practicing experience of at least three consecutive years (five years in the 1997 Schedule) in a country or region where he is admitted. ${ }^{243}$ Other representatives shall be members of the bar of a country or region where they shall have practiced for at least two consecutive years (three years in the 1997 Schedule). ${ }^{244}$ It seems that the requirements were meant to protect domestic consumers by preventing foreign law firms from staffing the representative offices with junior attorneys. ${ }^{245}$

\section{Presence of Natural Persons}

In this regard, the Final Schedule provides "unbound except as indicated in horizontal commitments." 246 In the horizontal commitments, natural persons are subject to the immigration regulations and other relevant regulations regarding the entry and temporary stay of foreigners. ${ }^{247}$ The effect

238. See id. at Limitations on Market Access 3a-3b. In the language of the Final Schedules, foreign representative offices can only (a) provide clients with consultancy on the legislation of the country/region where the lawyers of the law firm are permitted to engage in lawyer's professional work, and on international conventions and practices and (b) to handle, when entrusted by clients or Chinese law firms, legal affairs of the country/region where the lawyers of the law firm are permitted to engage in lawyer's professional work. See id.

239. See Background Note, supra note $60, \$ 30$.

240. See The Lawyer's Law, supra note 212, art. II.

241. See Gao, supra note 10.

242. See Final Schedule, supra note 197, at Limitations on Market Access, 3e. For instance, a member of a law firm of a limited liability corporation. See id.

243. See id.

244. See id.

245. See Interview with Hongming Xiao, supra note 156.

246. Final Schedule, supra note 197, at Limitations on Market Accession, 4.

247. See id. at Horizontal commitments. The exceptions are: (1) The managers, executives and specialists defined as senior employees who temporarily move as intra-corporate transferees, of a corporation of a GATS member that has established a representative office, branch or subsidiary within China, are permitted entry for an initial stay of three years; (2) The managers, 
of this "unbound" banner is that China will reserve its regulation power on the presence of natural persons, mainly by immigration methods. ${ }^{248}$

Listing such a condition in its Schedule is critical since, under GATS, it would otherwise be considered a violation of the "national treatment" provision. National treatment under GATS means de facto equal treatment between domestic and foreign service providers, meaning treating foreign vendors "no less favourable [sic] than that it accords to its own like services and service suppliers."249 "A measure or treatment, whether formally identical or formally different, shall be considered to be less favorable (and thus violating GATS principle) if it modifies the conditions of competition in favor of domestic services or service suppliers."250

It follows that unintentional regulative actions may constitute de facto discrimination if it leads to discriminatory effects. ${ }^{251}$ In this way, GATS explicitly includes in the text the issue that has only been developed in previous WTO agreements like GATT through legal dispute cases. ${ }^{252}$ The rough test of de facto discrimination and the current round of GATS renegotiation, by placing additional constraints on "domestic regulation," pose the most serious new threats to democracy. ${ }^{253}$

\section{Residence Requirement}

In order to counter the under-staffing phenomena in which everyday operations are maintained by a secretary with called-on assistance from "fly by night" lawyers, ${ }^{254}$ all representatives shall be resident in China for no less than six months each year. ${ }^{255}$ The 180 -day residence may qualify the resident attomeys for income tax purposes. ${ }^{256}$

executives and specialists defined as senior employees who are engaged in foreign invested enterprises within China, of a corporation of other GATS members, are permitted a long-term entry as stipulated in the terms of contracts concerned or an initial stay of three years, whichever is shorter. See id. at Limitations on Market Access, 4a-b.

248. See id. pt. I.

249. GATS, supra note 24 , art. XVII(1).

250. Id. art. XVII(3).

251. See Woodroffe, supra note 15, at 22.

252. See id.

253. See generally Sinclair, supra note 18 , at 13.

254. As a matter of fact, market seems to be at least as effective, if not more so, as government intervention in countering the under-staffing problem. See discussion infra regarding the competitive advantage of sufficiently staffed Representative Offices in getting assignments.

255. See Final Schedule, supra note 197, at Limitation on National Treatment, 3.

256. See Interview with Hongming Xiao, supra note 156. 


\section{Restrictions on Hiring Chinese National Registered Lawyers ${ }^{257}$}

Representative offices shall not employ "Chinese national registered lawyers" outside of China. ${ }^{258}$ This hiring restriction and restriction on partnership with local law firms are undivided parts of the above-mentioned restriction on host country law practice. Otherwise, by employing or associating with locally qualified lawyers, foreign law firms could circumvent the restriction on Chinese law practice and expand into the fields of representation before a court. ${ }^{259}$

\section{B. Remaining Business}

Although China is poised to play by international rules, this is not the end of the story. There remain at least three issues worth discussing:

\section{How "like" is "like?"}

Both the awarding of MFN and national treatment and the imposition of a "public order exception" are to be awarded to "like services and service suppliers." 260 Since GATS applies to four different modes of supplying services: cross border, consumption abroad, commercial presence, and the presence of natural persons extending equal treatment to services which are like to each other means that governments cannot discriminate amongst companies which supply services in these different ways. ${ }^{261}$ Since standards and qualifications are unlikely to be exactly the same in any two countries, the question is how much difference justifies a pronouncement of unlikeness? For instance, how real is the difference between civil law and common law as reflected in lawyering and legal market?

The most appropriate basis for comparing services shall be a "notion that is related to the economically meaningful concepts of directly competitive

\section{See Report of the Working Party, supra note 222, at 67.}

In response to questions from members of the Working Party, the representative of China clarified that 'Chinese national registered lawyers,' as indicated in China's Schedule of Specific Commitments, were those Chinese nationals who had obtained a lawyer's certificate, were holding a Chinese practicing permit and Id. were registered to practice in a Chinese law firm.

258. See Final Schedule, supra note 197, at Limitation on National Treatment, 3. It is unclear why the drafters need the phrase "outside of China." It seems odd to assume that employment of Chinese licensed lawyers is permitted inside of China since it would contradict the WTO Members' intention. It is noticeable that there is no equivalent term in the Chinese version of the Final Schedule.

259. See Background Note, supra note 60, 935.

260. See discussion, infra pt. IV.B.2 regarding "public order" exception.

261. See Woodroffe, supra note 15 , at 27. 
or substitutable and follows the logic of the market place."262 This is the notion of "end uses," meaning whether consumers treat the services in question as substitutes. ${ }^{263}$

China is enacting a new law on property rights during which two schools of thought, modeled after civil law and the Anglo-American system respectively, are fiercely competing with each other for front page. ${ }^{264}$ The civil law school, rooted in the Roman law idea of dominium, i.e., absolute right over a thing, defines property as the ownership of things, moveable and immovable, while excluding from "property" in a legal sense any other kind of economic right. ${ }^{265}$ The Anglo-American school notices the actual functions of property in industrial society where parties who have acquired the economic substance, but not the legal title, are increasingly exercising actual control functions. ${ }^{266}$ It will be interesting to witness the impact that this statute, or the clients' choices, has on foreign lawyers and their practice. ${ }^{267}$

\section{2. "Public order" and "Security" exceptions to MFN}

While the maintenance of public order is not an objective listed in the general exceptions provision of GATT $1994,{ }^{268}$ the difference between goods and services sectors, and especially the sensitive national character of trade in legal services, necessitates such an exception in trade in legal services. Under GATS, Members are not prevented from adopting or enforcing any measures that are "necessary to protect public morals or to maintain public order," 269 or taking any action that "it considers necessary for the protection of its essential security interests." ${ }^{\text {270 }}$ However, the public order exception may be invoked "only where a genuine and sufficiently serious threat is posed to one of the fundamental interests of society," ${ }^{271}$ and shall not be applied in a manner which will constitute a means of arbitrary or unjustifiable discrimination between countries where like conditions prevail, or a disguised restriction on trade in services. ${ }^{272}$

262. See Mattoo, supra note 33, at 21.

263. See id.

264. For a commentary on the debate, see Guodong Xu, Dui Zheng Cheng Si Jiao Shou de Lunzhan Lunwen de Guancha (Comments on Debates on Professor Zheng's Article), available at http://www.law-thinker.com/detail.asp?id=1081 (last updated May 20, 2002).

265. See PHILP P. WIENER, DictionaRY OF THE HiSTORY OF IDEAS Vol. 3, at 655 (19731974).

266. See id.

267. Although theoretically regulators can always claim and try to justify any "unlikeness" based on these variances, they have to, once challenged, satisfy a panel of trade experts whose decisions are not always predictable and favorable.

268. See Mattoo, supra note 33, at 11 n.12.

269. GATS, supra note 24 , art. XIV(a).

270. Id. art. XIV 1(b).

271. Id. art. XIV(a) n.5.

272. See id. art. XIV. 
"With the exception of general principles underlying broad doctrines such as the 'common law' or 'civil law,' legal rules are jurisdictionspecific,"273 and they are based on different ideological values and social regimes. It seems only natural that legal regulators would require foreign service vendors to ensure respect for the core values of the host society. ${ }^{274}$ Arguments aside, Chinese regulators are extremely concerned about any attempt to undermine its socialist national security. Thus, it shall not be a surprise that criminal defense of suspects indicted with violations of "national security" be precluded from foreign legal experts. ${ }^{275}$

\section{Domestic Regulation and Self-Regulation}

Although domestic regulatory measures (measures relating to qualification requirements and procedures, technical standards and licensing requirements) are not subject to scheduling under Articles XVI and XVII, ${ }^{276}$ many members have scheduled them in the legal services sector. ${ }^{277}$ Most of these measures are licensing and qualification requirements. ${ }^{278}$

GATS mandates that "[m]embers shall not apply licensing and qualification requirements and technical standards that nullify or impair [any existing sectoral] commitments in a manner which ... could not reasonably have been expected of that Member at the time the specific commitments in those sectors were made. ${ }^{2279}$ In the extreme, this provision could be read as "grandfathering" all existing restrictive requirements. ${ }^{280}$

To ensure that any domestic regulation measures "do not constitute unnecessary barriers to trade in services," GATS calls upon the Council for Trade in Services to develop any necessary disciplines. ${ }^{281}$ Pending the entry into force of any such discipline, "each Member shall ensure that all measures of general application affecting trade in services are administered in a reasonable, objective, and impartial manner." ${ }^{282}$ However, who decides what

273. Canadian Bar Association, supra note 58, at 14. In terms of legal families, there are at least Romano-Germanic Law, Common Law, Socialist Law, Hindu Law, Muslim Law, Laws of the Far East, Black Africa and Malagasy Law. See Background Note, supra note 60, $\mathbb{1} 7$.

274. See Canadian Bar Association, supra note 58, at 16.

275. See Final Schedule, supra note 197. Some renowned Chinese law experts at American institutions have successfully counseled the family members, who are residents of the U.S., of some of the indicted. See id. However, these probably should not be interpreted as unauthorized practices of Chinese law since China doesn't schedule mode 2 of the trade in legal service, i.e., consumption abroad. See id.

276. See Background Note, supra note 60, 1 68. See also GATS, supra note 24, arts. VI, XVI \& XVII.

277. See Background Note, supra note 60, 166 . Twenty six Members have made such scheduling. See id.

278. See id.

279. GATS, supra note 24 , art. VI(5)(a)(ii).

280. See Mattoo, supra note 33, at 23.

281. See GATS, supra note 24, art. VI(4) (emphasis added)

282. Id., art. VI(1) (emphasis added) 
is an "unnecessary barrier" and what is "reasonable, objective, and impartial?" The fact that trade experts, instead of democratically-elected representatives, have the final say worries many. ${ }^{283}$

On the other hand, for governments to avoid unnecessary confrontation with other Members on domestic regulation, it is probably wise to rely more on self-regulation to achieve the same policy goals. There have been proposals suggesting that the government delegate the regulation power to the All-China Lawyer Association and subject foreign lawyers to the same disciplines as Chinese lawyers. ${ }^{284}$ It is believed that these proposals, like many basic ideas behind the current regulatory measures, draw fire from Japanese models, the one with the most restrictive force. ${ }^{285}$

Although self-regulation may help shift the burden and criticism away, ${ }^{286}$ the regulators can not play ostrich as to the professional codes the bar associations come up with. ${ }^{287}$ For the first time in a multilateral agreement, it is recognized that "certain business practices" of service suppliers may restrain competition and thereby restrict trade in services. ${ }^{288}$ Therefore, Members have a general obligation to consult on such practices when so requested by another member, and to exchange information with a view to eliminate them. ${ }^{289}$

\section{CONCLUSION: IN THE WAKE OF WTO ACCESSION}

China's offer in legal services is far less than adequate from other members' point of view. ${ }^{290}$ However, since members have placed priority on issues of financial services and telecommunications rather than legal services,

283. See Woodroffe, supra note 15 , at 40.

284. See Interview with Hongming Xiao, supra note 156.

285. For a comparative study, see J. Ryan Dwer III, The Door Only Opens Out: Japan's Special Measures Law for Regulation of Foreign Attorneys, 18 HAWAII L. REV. 257 (1996).

286. See Canadian Bar Association, supra note 58, at 17. As Canadian negotiators put it, the association's rules concerning matters which relate to the public interest shall not be subject to review by a third-party dispute settlement body. See id. "[T] hese rules involve matters which are fundamental to the public interest, such as who can practice law, what standards of behavior they are required to meet, and how they must practice." $1 d$. "Such issues of public protection should not be left to a panel of "experts' from other countries with little or no familiarity of (host country's) legal history and culture." Id.

287. See Introduction to the GATS, supra note 14, at 7. Article $\mathrm{XX}$ is the general obligation of the GATS that has no GATT counterpart. See id.

288. See GATS, supra note 24 , art. IX(1).

289. See id. art. IX(2).

290. See Follow Up Letter to USTR Regarding China's Accession to WTO, available at http://www.uscib.org/index.asp?documentID=1297 (last visited Sept. 13, 2002). For instance, during the negotiations on China's accession into WTO, in a letter addressed to then U.S. Trade Representative Charlene Barshefsky, the U.S. See id. Council for International Business made specific demands on behalf of the American legal profession. See id. Among others, China should extend "complete reciprocity" to legal services and permit American firms to hire Chinese attorneys licensed to practice law in China. See id. And there should be no restrictions on the number of licenses or locations for legal practice. See id. 
the negotiators have been able to agree to "the minimal market opening China has already offered in this realm." 291

It is always the concern whether and to what extent the Chinese government can live up to its words. There were new rounds of speculation sparked, for instance, by MoJ's recently reported willingness to award firms from Hong Kong, Macao and Taiwan rights to practice mainland law, after substantial lobbying by Hong Kong's Law Society for China to widen access. ${ }^{292}$ The new rule, in draft form, did not give details on how to define a "Hong Kong firm." Many American law firms are qualified to practice Hong Kong law and their Hong Kong branches are staffed with Hong Kong lawyers. ${ }^{293}$ It seems equally odd to either grant or deny them the preferential treatment in Chinese law practice. As luck would have it, the finalized rule grants "Hong Kong law firms," still an undefined term, exactly the same rights as extended to "foreign law firms" in the Stipulations issued by the MoJ earlier this year. ${ }^{294}$

Although legal services providers "came away with little from the WTO negotiations, their clients in banking, telecommunications and consumer products did well."295 This may soon translate into billable hours for American lawyers. It is generally true for other foreign investments as well since, to many foreign investors, "China will remain a tricky place to do business, and lawyers will continue to be valuable guides."296

On top of vast opportunities provided by WTO, there is also the Olympics, which is predicted to provide an estimated $\$ 22$ billion of infrastructure investment alone. ${ }^{297}$ The hosting of the 2008 Olympics Games, signaling a $0.3 \%$ annual growth as predicted by Goldman Sachs, ${ }^{298}$ will surely invigorate the foreign direct investment.

The Chinese economy has been undergoing major reshufflings characterized by a massive Going West campaign ${ }^{299}$ which encourages businesses to set up operations in China's Wild West, ${ }^{300}$ and state owned

291. Clarke, supra note 81 , at 118.

292. See Jane Moir, Lawyers See Opening, South ChIna Morning Post, Jan. 14, 2002 , at 1.

293. See id.

294. See Measures on the Management of Representative Offices set up by Law Firms of the Hong Kong and Macau Special Administrative Regions in the Mainland, issued by PRC Ministry of Justice on February 20, 2002, effective April 1, 2002, available at http://www.info.gov.hk/justice/new/depart/doc/setup_law_firm_e3.pdf (last visited Sept. 15, 2002). For the Stipulations, see supra note 91 and accompanying text.

295. McCollam, supra note 7.

296. Id. (quoting Howard Chao, partner of international law firm of O'Melveny \& Meyers).

297. Chinese Market Sparks Optimism Among U.S. Investors, WALL STREET JOURNAL, July 17, 2001.

298. See id.

299. See Notice of the State Council on Certain Policy Measures for the Implementation of the Great Development of the Western Region, promulgated on Oct. 26, 2000, China Laws for Foreign Business/Business Regulation 4, CCH Asia Pacific (1998).

300. See id. 
enterprise reform which typically involves vast corporatization, or "limited privatization." The demand for sophisticated legal services, especially in banking, corporate finance, and cross-border mergers and acquisitions, has far exceeded the capacity of the domestic bar, allowing Western lawyers to fill the gap.

Attracted by the long-term booming business opportunities, more and more foreign law firms are, despite the fact that few firms seem to operate profitably, willing to create a bridgehead and see a return only over the long term. It still seems unlikely that the foreign legal professionals will be tendered admission tickets for the national bar exam. ${ }^{301}$ It is also doubtful that the relaxation of the one-city rule would alleviate the high concentration of foreign firms in major cities, unless foreign investment continues to pour into inland areas.

The staffing of linguistically qualified and willing talents are always the concern because China has yet to adopt English as the default language for business dealings and young associates tend to be reluctant to accept a posting far away from their headquarters. ${ }^{302}$ The two-year practice threshold is especially annoying to the firms who want to send young lawyers to China to be trained. ${ }^{303}$

Commercial presence (Mode 3 of trade in legal services) has been, and will remain, the turf battle among foreign law firms. Clients, increasingly sophisticated and cost conscious, tend to now inquire more about the staffing of the Representative Offices to ensure such assignments as due diligence can be conducted locally without incurring the sometimes ridiculously high cost of international airfare and hotel expenses of those lawyers tentatively seconded from headquarters for a specific deal only. ${ }^{304}$

All in all, the GATS and China's Accession to the WTO will represent an optimistic step forward for U.S. lawyers in the international arena, although the actual impact remains to be seen. The entry may necessarily stimulate a new wave of law reform in areas of transparency and independence, impartial review of administrative actions. ${ }^{305}$ To facilitate the PRC's compliance with WTO accession requirements, fostering a more open, law-abiding China is a must. $^{306}$

301. See Press Release, supra note 187. The exam is now known as National Uniform Judicial Examination. See id.

302. See McCollam, supra note 7.

303. See id. at 5.

304. Interview with $\mathrm{Li} \mathrm{Li}$, former partner, Pillsbury Winthrop (Feb. 20, 2002).

305. See Jerome Cohen, Comment, China's Troubled Path to WTO, INT'L FINANCIAL L. REv. (Sept. 2001), available at http://www.legalmediagroup.com/IFLR/includes/print.asp? SID=3019 (last visited Sept. 29, 2002).

306. See id. 
At minimum, no new procedural hurdles will be erected and application (to set up a Representative Office) per se will not be as tedious. ${ }^{307}$ China will also be obligated to continue to negotiate with other members in order to further liberalize international trade in services, including legal services.

However, to surf in the seemingly huge legal market safely and productively, U.S. firms will need to be armed with a realistic point of view. After all, embedded national character of legal services aside, Chinese practitioners are understandably concerned that overflow of foreign practitioners will lead to chaos and jeopardize the national legal market, which is by and large still an "infant industry" by all standards. ${ }^{308}$

307. Article VI(3) of GATS requires the authority to decide and inform the applicant, within a reasonable period of time, of any submission of the application and, without undue delay, notify the applicant of their status upon request. See GATS, supra note 24, art. VI(3).

308. See The Penguin Dictionary of Economics, available at http://www.xrefer.com/ entry/445523 (last visited Sept. 29, 2002). The "infant-industry" argument commonly supports retention of protective measures to promote the creation of a local industry until the industry has reached its optimum size to obtain significant economies of scale. See id. However, the text of the GATS does not support a stand-alone right to protect "infant industry" beyond those scheduled measures. See id. As a matter of fact, because of the wide-ranging nature of GATS, the ability of a WTO Member to protect its own nascent industries by regulating domestic market could be open to a WTO challenge. See Woodroffe, supra note 15, at 13. 